ISSN 0103-9954

\title{
SOLOS E GEOAMBIENTES DO PARQUE NACIONAL DO VIRUÁ E ENTORNO, RORAIMA: VISÃO INTEGRADA DA PAISAGEM E SERVIÇO AMBIENTAL ${ }^{1}$
}

\section{SOILS AND GEOENVIRONMENTS OF THE NATIONAL PARK OF VIRUÁ AND SURROUNDING, RORAIMA: INTEGRATED VISION OF THE LANDSCAPE AND ENVIRONMENTAL SERVICE}

Bruno Araujo Furtado de Mendonça² Elpídio Inácio Fernandes Filho ${ }^{3}$

Carlos Ernesto Gonçalves Reynaud Schaefer ${ }^{4}$ Felipe Nogueira Bello Simas ${ }^{5}$

José Frutuoso do Vale Junior ${ }^{6}$ Beatriz de Aquino Ribeiro Lisboa ${ }^{7}$ Júlia Gaio Furtado de Mendonça ${ }^{8}$

\section{RESUMO}

O Parque Nacional (PARNA) do Viruá ocupa 227.011 ha, na região do baixo Rio Branco, Roraima. A região compreende um extenso mosaico de ambientes complexos inundáveis, florestais e não florestais. Este trabalho teve como objetivo geral detalhar os aspectos pedológicos e geoambientais do Parque e entorno, em uma visão integrada da paisagem e, além disso, estimar o estoque de carbono nos solos e geoambientes. Foram descritos e coletados 29 perfis de solos nas principais fitofisionomias de Campinaranas e Florestas do Parque e entorno. Destacaram-se os seguintes: Espodossolo Humilúvico, Neossolo Quartzarênico, Neossolo Flúvico, Neossolo Litólicos, Latossolo Vermelho-Amarelo, Latossolo Vermelho, Cambissolo Háplico, Cambissolo Flúvico, Gleissolo Háplico e Plintossolo Háplico. Os solos apresentaram distribuição espacial com limites abruptos e com forte associação entre as fitofisionomias. Foram agrupados em três pedoambientes: (1) solos arenosos das campinaranas, (2) solos associados aos inselbergs e adjacências e (3) solos aluviais. Foram mapeadas e descritas 18 unidades geoambientais no Parque e entorno. Os geoambientes predominantes no Parque foram: Planícies Arenosas e Paleodunas com Campinarana Graminosa e Arbustiva em Neossolos Quartzarênicos hidromórficos e Espodossolos; e Planícies de Inundação e Terraços com Floresta de Igapó sobre solos hidromórficos arenosos, com respectivamente $24,6 \%$ e $20,1 \%$ da área estudada. Em termos de estoque total de carbono nos solos, destacaram-se os geoambientes dos complexos arenosos das Campinaranas e associações, com 9450,9 Gg C. A grande extensão e representatividade dos complexos arenosos das Campinaranas fazem do PARNA Viruá uma Unidade de Conservação de proteção integral com forte vocação para preservação e conservação de sistemas arenícolas amazônicos. As áreas sob o domínio de Espodossolos possuem os maiores estoques de carbono orgânico e os complexos arenosos das Campinaranas e associações representam os geoambientes mais relevantes na prestação de serviços ambientais de conservação do carbono nos solos.

Palavras-chave: campinaranas; Amazônia; solos arenosos; estoque de carbono.

1. Parte da Tese de Doutorado do primeiro autor, apresentada à Universidade Federal de Viçosa.

2. Engenheiro Florestal, Doutor em Solos e Nutrição de Plantas, Departamento de Solos, Universidade Federal de Viçosa, CEP 36571-000, Viçosa (MG). Bolsista do CNPq. brunoafmendonca@gmail.com

3. Engenheiro Agrônomo. Dr., Professor Associado do Departamento de Solos, Universidade Federal de Viçosa, CEP 36571-000, Viçosa (MG). elpidio@ufv.br

4. Engenheiro Agrônomo. PhD em Solos, Professor Associado do Departamento de Solos, Universidade Federal de Viçosa, CEP 36571-000, Viçosa (MG). carlos.schaefer@ufv.br

5. Engenheiro Agrônomo. Dr. Professor Substituto do Departamento de Solos, Universidade Federal de Viçosa, CEP 36571-000, Viçosa (MG). fsimass@yahoo.com.br

6. Engenheiro Agrônomo. Dr., Professor Associado do Departamento de Solos e Engenharia Agrícola, Universidade Federal de Roraima, Campus Cauamé, BR 174, Km 12, Bairro Monte Cristo, CEP 69300-000, Boa Vista (RR). vale.junior@click21.com.br

7. Bióloga, Analista Ambiental do Parque Nacional do Viruá, ICMBio/Roraima, Av. Sebastião Diniz, 662, Centro, CEP 69301-040, Boa Vista (RR). belisboa@gmail.com

8. Graduanda em Engenharia Florestal, Estagiária do Departamento de Solos, Universidade Federal de Viçosa, CEP 36571-000, Viçosa (MG). juliagaio@hotmail.com

Recebido para publicação em 14/06/2011 e aceito em 27/10/2011 


\begin{abstract}
The Viruá National Park (PARNA Viruá) occupies 227.011 ha, in the region of the low 'Branco' river, in Roraima state. This area includes an extensive mosaic of complex seasonally flooded forested and nonforested environments. The present work aimed to characterize pedological aspects and identify the geoenvironmental units of the Park and surroundings, in an integrated vision of the landscape and,additionally, estimate the carbon stocks in soils and geo-environments. We described and collected 29 soil profiles according with the main vegetation types of Campinaranas and Forests of PARNA Viruá and surroundings. The main soil classes are: Espodossolo Humilúvico, Neossolo Quartzarênico, Neossolo Flúvico, Neossolo Litólicos, Latossolo Vermelho-Amarelo, Latossolo Vermelho, Cambissolo Háplico, Cambissolo Flúvico, Gleissolo Háplico and Plintossolo Háplico. The soils present an spatial distribution marked by abrupt limits and close association with the vegetation type. We identified three pedo-environments: (1) sandy soils of the Campinaranas; (2) soils associated with the inselbergs and adjacencies; and (3) alluvial soils. We mapped and described 18 geoenvironmental units in PARNA Viruá National Park and surroundings. The main geoenvironments are: i) Sandy plains and Paleodunes with grassy and arborous Campinarana on 'Neossolos Quartzarênicos hidromórficos' and 'Espodossolos'; and Floodplains and; ii) Terraces with Igapó Forest on sandy hydromorphic soils, occupying $24.6 \%$ and $20.1 \%$ of the studied area, respectively. In terms of total soil carbon stocks, the geo-environments of the sandy complex of Campinaranas and associations stand out, with $9450.9 \mathrm{Gg} \mathrm{C}$. The great extension and representativeness of the sandy areas of Campinaranas characterize PARNA Viruá Park as an important conservation unit for protecting Amazonian sandy soil systems. The areas under the domain of 'Espodossolos' possess the largest stocks of organic carbon and the sandy areas of Campinaranas and associations represent the most relevant geo-environment in terms of Park protecting environmental services and conservation of carbon in soils.
\end{abstract}

Keywords: Campinaranas; Amazon; sandy soils; carbon stocks.

\section{INTRODUÇÃO}

O Parque Nacional (PARNA) do Viruá, localizado na região do baixo Rio Branco em Roraima, ocupa 227.011 ha, cobertos em sua maior parte pelo ecossistema das Campinaranas, as quais são caracterizadas como formações vegetais típicas das áreas de clima úmido e solos arenosos hidromórficos (VELOSO et al., 1991). O PARNA do Viruá representa uma das mais extensas Unidades de Conservação (UC) de Proteção Integral com ocorrência desta tipologia vegetal no Brasil, revelando, ainda, uma extensa faixa de transição com ecossistemas florestados em seu limite nordeste. Isto confere uma enorme importância para a proteção de um grande mosaico de formações florestadas e abertas em um ambiente submetido a inundações periódicas.

Segundo Ab'Saber (2002), o baixo rio Branco e suas planícies coalescentes, onde está localizado o PARNA do Viruá, constitui um ecossistema local de suportes ecológicos singulares, com a presença de campos de dunas, em uma região deprimida existente no espaço meridional de Roraima, um "psamobioma". Do ponto de vista pedológico, a região compreende um grande domínio de Espodossolos e Neossolos Quartzarênicos, de- senvolvidos sobre areias quartzosas. Alguns estudos realizados na Guiana Francesa e no Brasil têm mostrado que os Espodossolos podem ser formados pela transformação de uma cobertura latossólica inicial, sobre vários tipos de material de origem (LUCAS et al., 1984; ANDRADE, 1990; DUBROEUCQ et al., 1991), sendo o Espodossolo considerado como um estádio final de degradação das coberturas pedológicas tropicais (BOULET et al., 1984). Além disso, este processo pode ser o principal mecanismo responsável pelo aplainamento geral do terreno observado nesta região (MAFRA et al., 2002).

Predomina o relevo plano a suave ondulado, em um sistema arenícola e, na maior parte, hidromórfico, desenvolvido de materiais de origem retrabalhados do Pré-Cambriano, os sedimentos de idade Plio-Pleistocênica, denominados Formação Içá e, ainda, Coberturas Eólicas Holocênicas (BRASIL, 1975). Esta unidade geológica corresponderia, em sua maioria, a mantos arenosos profundos, formados por pedogênese in situ de sedimentos Cenozoicos ou rochas ígneas e metamórficas, como demonstram os estudos no Estado do Amazonas (ALTEMULLER e KLINGE, 1964; LUCAS et al., 1984; BRAVARD e RIGHI, 1990; ANDRADE et al. 1997). Neste sentido, as condições climáticas de elevada taxa de precipitação pluvial desta região contribuem direta- 
mente para os processos de podzolização e arenização destes solos que, por sua vez, são associados à elevada lixiviação e consequente empobrecimento químico (SCHAEFER et al., 2007).

Dessa forma, os estudos pedológicos aliados às características geomorfológicas, geológicas e da cobertura vegetal permitiram a individualização de unidades geoambientais, com características ecogeográficas e problemas geoambientais próprios (TRICART e KIEWIETDEJONGE, 1992; SCHAEFER, 1997). Estas unidades constituem um referencial integrado a ser levado em consideração no processo de planejamento e monitoramento dos recursos naturais (SCHAEFER et al., 2000; SIMAS, 2002). Neste contexto, tendo em vista que o Parque Nacional do Viruá não possui informações relativas ao meio físico em escalas adequadas ao seu planejamento e monitoramento, este trabalho teve como objetivo contribuir com um estudo mais detalhado dos aspectos pedológicos e geoambientais como um subsídio ao Plano de Manejo do Parque.

Além disso, a partir da integração dos dados estimaram-se os estoques de carbono orgânico nos solos e geoambientes. A conservação dos estoques de carbono nos solos consiste em um dos muitos serviços ambientais oferecidos pela região amazônica, os quais podem ser agrupados em três grupos: biodiversidade, água e carbono (FEARNSIDE, 2003). O interesse pela ciclagem do carbono, tanto nas emissões para atmosfera quanto nos sequestros, tem sido cada vez mais intenso desde o Protocolo de Kyoto (UM-FCCC, 1997). Nesse sentido, foram discutidos alguns aspectos do serviço ambiental de conservação (sequestro) do carbono nos solos e geoambientes do Parque Nacional do Viruá.

\section{MATERIAIS E MÉTODOS}

\section{Área de estudo}

Localizado no centro-sul do Estado de Roraima, no município de Caracaraí, às margens da BR 174, distante cerca de $190 \mathrm{~km}$ da capital Boa Vista, o Parque Nacional (PARNA) do Viruá estende-se por um cenário bioclimático regional fortemente transicional na Amazônia. Na classificação de Köppen, o clima do setor sul do Parque é definido como Amw' (chuva do tipo monção), enquanto na porção nordeste do Parque é Aw (verão úmido e inverno seco). De acordo com os dados da Agência Nacional de Águas (ANA, 2009), obtidos na estação meteorológica em Caracarai, a série histórica de 30 anos de precipitação média anual revela uma va- riação de precipitação anual de 1.300 a $2.350 \mathrm{~mm}$, com média de $1.794 \mathrm{~mm}$.

A geologia é caracterizada principalmente por extensas coberturas arenosas de origem sedimentar fluvial, eólica ou pelo intemperismo, com a presença de rochas ígneas vulcânicas ou metamórficas em serras e residuais esparsos (BRASIL, 1975; CPRM, 2000). Nesta região ocorrem feições diferenciadas por arenização, sendo no interflúvio rio Branco-rio Anauá, a fase mais evoluída, ou seja, a área mais consolidada dentro dos padrões interpretados (BRASIL, 1975). A altitude média do Parque é de 46 metros, em um relevo predominantemente plano. Os solos são arenosos e hidromórficos em sua maioria, do tipo Espodossolos e Neossolos Quartzarênicos.

Predominam as Campinaranas e caracterizam-se por uma paisagem marcante, de exceção à Floresta Tropical envolvente. Essa vegetação é fortemente influenciada pelos ciclos sazonais e pelas variações do lençol freático, em gradações fitofisionômicas associadas a diferentes níveis de hidromorfismo. Conforme aumenta o encharcamento dos solos, as Campinaranas Florestadas são substituídas por formações de Campinarana Arbórea e Arbustiva, passando pelas Gramíneo-Lenhosas até puramente herbáceas. Os relevos residuais de núcleos de rochas resistentes em forma de inselbergs (palavra de origem alemã, "monte ilha"; é um relevo que se destaca de seu entorno já aplainado, caracteriza um relevo residual) e as rampas pedimentadas apresentam-se salientes da topografia geral baixa e aplainada das áreas de acumulação, inclusive pela cobertura vegetal diferenciada, as Florestas Ombrófilas. Os inselbergs constituem formas de relevo que se destacam de seu entorno já aplainado, caracterizando-se por ser um relevo residual.

\section{Coleta, preparo e análises das amostras de solo}

Foram coletados 29 perfis de solos nas principais fitofisionomias das Campinaranas e Florestas do PARNA do Viruá e entorno. A distribuição dos perfis foi representativa para todas as fitofisionomias do Parque. A descrição e amostragem dos perfis foram realizadas de acordo com o proposto por Santos et al. (2005). Todos os perfis de solos descritos e coletados foram classificados de acordo com o Sistema Brasileiro de Classificação de Solos (EMBRAPA, 2006) até o $4^{\circ}$ nível categórico. Após coletadas as amostras no campo, as mesmas foram levadas aos laboratórios do DPS-UFV, onde foram secas ao ar, destorroadas e peneiradas em malha de 
$2 \mathrm{~mm}$, visando obter amostras na forma de terra fina seca ao ar (TFSA), sendo submetidas às seguintes análises:

\section{Análises químicas}

$\mathrm{O}$ pH em água e em $\mathrm{KCl} 1 \mathrm{~mol} \mathrm{~L}^{-1}$ foram determinados na suspensão solo:solução 1:2,5. As concentrações de cálcio, magnésio e o alumínio trocáveis foram extraídas com $\mathrm{KCl} 1 \mathrm{~mol} \mathrm{~L}^{-1}$, na proporção 1:20, e determinadas por espectrometria de absorção atômica. O potássio e sódio trocáveis foram extraídos com solução de Mehlich-1 e determinados por fotometria de chama. $\mathrm{O}$ fósforo foi extraído com solução de $\mathrm{HCl} 0,05 \mathrm{~mol} \mathrm{~L}^{-1}$ e $\mathrm{H}_{2} \mathrm{SO}_{4} 0,025 \mathrm{~mol} \mathrm{~L}^{-1}$ (Mehlich-1) e determinado por colorimetria na presença de ácido ascórbico (DEFELIPO e RIBEIRO, 1997). O ferro, zinco, manganês e cobre foram extraídos com solução Mehlich-1, e determinados por espectrometria de absorção atômica. A acidez potencial foi determinada por titulação com $\mathrm{NaOH}$ $\left(0,025 \mathrm{~mol} \mathrm{~L}^{-1}\right)$ da extração de acetato de cálcio $0,5 \mathrm{~mol} \mathrm{~L}^{-1}$ a pH 7,0. O Carbono Orgânico Total (COT) foi determinado pelo método de Yeomans e Bremner (1988), através da oxidação da matéria orgânica via úmida com $\mathrm{K}_{2} \mathrm{Cr}_{2} \mathrm{O}_{7} 0,167 \mathrm{~mol} \mathrm{~L}^{-1} \mathrm{em}$ meio sulfúrico com aquecimento externo. A Matéria Orgânica (MO) calculada pela multiplicação do fator 1,724 .

\section{Análises físicas}

A granulometria foi determinada a partir da dispersão de $10 \mathrm{~g}$ de TFSA com $\mathrm{NaOH} 0,1 \mathrm{~mol} \mathrm{~L}^{-1} \mathrm{e}$ agitação horizontal com $50 \mathrm{rpm}$ durante 16 horas. Em seguida, as frações areia grossa e fina foram separadas por tamização em peneiras com malhas de $0,2 \mathrm{~mm}$ e $0,053 \mathrm{~mm}$ de abertura, respectivamente. A fração argila foi determinada pelo método da pipeta, e a fração silte calculada por diferença (RUIZ, 2005).

\section{Unidades geoambientais}

Para a estratificação das unidades geoambientais, utilizou-se um método pedogeomorfológico, estratificando as unidades e identificando as características ecogeográficas e problemas geoambientais associados (TRICART e KIEWIETDEJONGE, 1992; SCHAEFER, 1997). O mapeamento geoambiental foi constituído de unidades fisiográficas distintas, baseadas em características pedológicas, geomorfológicas e de vegetação. $\mathrm{O}$ delineamento das unidades foi realizado dentro da escala mais detalhada possível da base de
1:100.000 disponível, a partir da interpretação visual da imagem do satélite Landsat TM (bandas 3, 4 e 5), de setembro de 2007 e abril de 2008, imagens do radar SRTM e fotografias panorâmicas aéreas georreferenciadas, além de dados secundários do Projeto RADAMBRASIL (1975) e CPRM (2000). As fotos aéreas de visada lateral e georreferenciadas foram obtidas em três sobrevoos de helicóptero em 24/05/2006, 04/12/2006 e 28/10/2008, e permitiram detalhar e reconhecer as principais formas de vegetação do Parque e seus solos e geoambientes associados. Para o mapeamento das unidades geoambientais utilizou-se o software ArcGIS 9.3.

\section{Estoque de Carbono no solo}

A partir da integração dos dados dos perfis de solos coletados e do mapeamento dos geoambientes, foi estimado o estoque de carbono no solo para cada unidade geoambiental, considerando a porcentagem de ocorrência dos solos. $\mathrm{O}$ estoque relativo de $C$ por perfil de solo $E C_{p}\left(\mathrm{~kg} \mathrm{~m}^{-2}\right)$ foi calculado para os horizontes A, B e $\mathrm{C}$ dos solos amostrados, multiplicando a concentração de C (\%), densidade do solo (DS) $\left(\mathrm{kg} \mathrm{m}^{-3}\right)$ e espessura $h(\mathrm{~m})$ do horizonte. A serrapilheira não foi incluída no cálculo em função de sua variabilidade amostral. O cálculo constituiu na soma dos estoques de cada horizonte, portanto, o estoque total refere-se à profundidade de coleta dos horizontes mais profundos de cada perfil amostrado. Para o cálculo da estimativa da densidade dos solos (DS), foram utilizadas equações que relacionam teor de argila (TA), carbono orgânico (CO) e pH com densidade do solo, obtidas a partir de dados de solos representativos da bacia Amazônica, de acordo com Bernoux (1998) e Bernoux et al. (1998). Para os solos com teor de argila $\leq 20 \%$ utilizou-se a seguinte equação: $\mathrm{DS}=0,0181 \times(100-\mathrm{TA}-5)-0,08 \times$ $\mathrm{CO}, \mathrm{r}^{2}=0,66$. Para os solos com mais de $20 \%$ de argila, o cálculo foi efetuado de acordo os seguintes grupos de solos: G1 - Cambissolos Háplicos - DS $=1,394-(0,0051 \times \mathrm{TA})-(0,037 \times \mathrm{CO}), \mathrm{r}^{2}=0,47 ; \mathrm{G} 2$ - Neossolos e Cambissolos Flúvicos, Gleissolos e Plintossolos - DS $=1,58-(0,0040 \times \mathrm{TA})-(0,050 \mathrm{x}$ CO) - $(0,047 \mathrm{x} \mathrm{pH}), \mathrm{r}^{2}=0,51$; e G3 - Latossolos DS $=1,404-(0,0040 \times \mathrm{TA})-(0,048 \times \mathrm{CO}), \mathrm{r}^{2}=0,71$. Onde: $\mathrm{DS}=$ densidade do solo em peso por volume $\left(\mathrm{g} \mathrm{cm}^{-3}\right) ; \mathrm{TA}=$ conteúdo de argila, após dispersão com $\mathrm{NaOH}$ 0,1 mol L- (\% [peso/peso] da fração de solo $<2 \mathrm{~mm}$ ); $\mathrm{CO}=$ carbono orgânico [\% (peso/ peso) da fração de solo $<2 \mathrm{~mm}$ ] (YEOMANS e BREMNER, 1988); $\mathrm{pH}=\mathrm{pH}$ em água. Tais agrupamentos de solos utilizam como base os seguintes 
critérios recomendados por Houghton et al. (1997) para inventários de carbono do solo: atividade de argila, saturação por bases e umidade do solo. No cálculo foram utilizados 30 perfis de solo: 29 coletados em trabalhos de campo e um Latossolo Amarelo de referência coletado pelo projeto RADAMBRASIL (1975), no alto rio Anauá.

\section{RESULTADOS E DISCUSSÃO}

\section{Distribuição e Caracterização dos Solos do PARNA Viruá}

Os solos classificados até o $2^{\circ}$ nível categórico (subordem), em ordem decrescente de número de perfis, foram: Espodossolo Humilúvico (6), Neossolo Quartzarênico (5), Neossolo Flúvico (3), Latossolo Vermelho-Amarelo (2), Latossolo Vermelho (2), Cambissolo Háplico (5), Cambissolo Flúvico (3), Gleissolo Háplico (1) Plintossolo Háplico (1) e Neossolo Litólicos (1) (Tabela 1). De certo modo, todas as classes de solos estudadas apresentam distribuição espacial com limites bem abruptos e com forte associação entre as fitofisionomias (Figura 1). $\mathrm{O}$ forte controle edáfico sobre as diferentes tipologias vegetais na escala estudada permitiu o agrupamento dos principais solos em três pedoambientes (Tabela 1).

\section{Solos arenosos das Campinaranas Espodossolos Humilúvicos}

Estes solos foram predominantes na paisagem das Campinaranas do PARNA Viruá. Ocorreram de maneira generalizada em todas as gradações fitofisionomias, desde as Campinaranas Florestadas até as Campinaranas Gramíneo-Lenhosas (Figuras 1, 2 e 3). Entretanto, apresentaram horizontes espódicos mais espessos, com variação de $0,1 \mathrm{a} 1 \mathrm{~m}$ de espessura, e com teor de carbono orgânico maior nas Campinaranas Florestadas (Tabela 2). Estas possuem solos mais ricos em matéria orgânica, presença de turfeiras e com nível do lençol freático pouco profundo; os horizontes $\mathrm{O}$ possuem cerca de $0,1 \mathrm{~m}$ de espessura, com cores bruno-avermelhadas-escuras $(2,5 \mathrm{YR}$ 2,5/3, úmido). Nas fisionomias arbóreo-arbustivas destacaram-se o horizonte E, mais espesso (maiores que $0,5 \mathrm{~m}$ ) e esbranquiçado, e o incremento de matéria orgânica $(\mathrm{MO})$ em profundidade associado ao aumento de P-Mehlich e CTC (Tabelas 2 e 3). As diferenciações destes solos, da mesma classe, principalmente no incremento de $\mathrm{MO}$ em subsuperfície, parecem estar condicionadas aos pequenos desníveis do terreno (plano), onde periodicamente as variações do nível do lençol freático formam ambientes (microrrelevos) mais ou menos inundados em condições diferenciadas para o suporte da vegetação.

TABELA 1: Pedoambientes, grupo de solos, número de perfis de solo coletados e vegetação correspondente no PARNA Viruá e entorno, Roraima.

TABLE 1: Pedoenvironments, soil groups, numbers of soils profile and vegetation type of PARNA Viruá National Park and surroundings, Roraima state.

\begin{tabular}{|c|c|c|c|}
\hline Pedoambientes & Grupos de solos & $\begin{array}{l}\text { No. perfis } \\
\text { de solo }\end{array}$ & Vegetação \\
\hline \multirow{2}{*}{$\begin{array}{l}\text { Solos arenosos das } \\
\text { Campinaranas }\end{array}$} & $\begin{array}{l}\text { Espodossolos } \\
\text { Humilúvicos }\end{array}$ & 6 & $\begin{array}{l}\text { Campinaranas Florestadas, } \\
\text { Arborizadas e Gramíneo Lenhosas }\end{array}$ \\
\hline & $\begin{array}{l}\text { Neossolos } \\
\text { Quartzarênicos }\end{array}$ & 5 & $\begin{array}{l}\text { Campinaranas Arborizadas e } \\
\text { Gramíneo Lenhosas }\end{array}$ \\
\hline \multirow{5}{*}{$\begin{array}{l}\text { Solos associados } \\
\text { aos inselbergs e } \\
\text { Adjacências }\end{array}$} & Cambissolos Háplicos & 5 & $\begin{array}{l}\text { Florestas Ombrófilas e Contato } \\
\text { Florestas/Campinaranas }\end{array}$ \\
\hline & $\begin{array}{l}\text { Latossolos Vermelho e } \\
\text { Vermelho-Amarelo }\end{array}$ & 4 & \multirow{3}{*}{$\begin{array}{l}\text { Florestas Ombrófilas Aberta e } \\
\text { Densa }\end{array}$} \\
\hline & Neossolo Litólico & 1 & \\
\hline & Plintossolo Háplico & 1 & \\
\hline & Gleissolo Háplico & 1 & Formações Pioneiras \\
\hline \multirow[t]{2}{*}{ Solos Aluviais } & Solos Aluviais & 6 & Florestas de várzea e igapós \\
\hline & TOTAL & 29 & \\
\hline
\end{tabular}




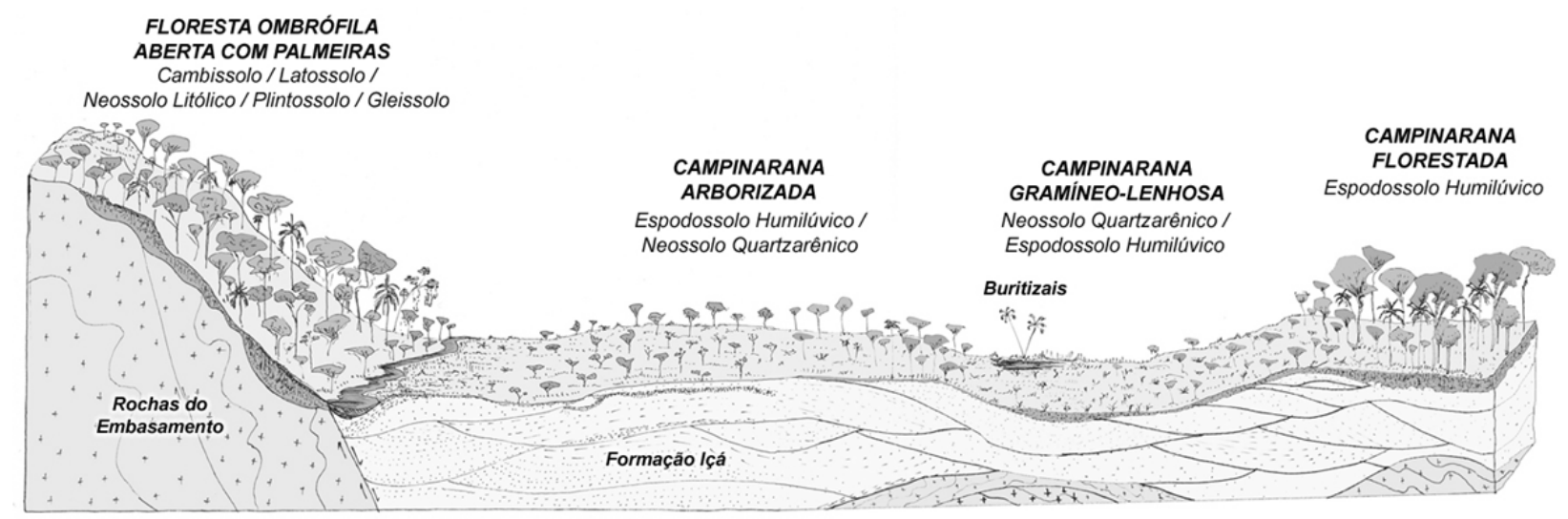

FIGURA 1: Paisagem representativa (fora da escala real) das formações complexas das Campinaranas, predominantes em grandes extensões do PARNA Viruá, e da Floresta Ombrófila Aberta; com as respectivas classes de solos e representações geomorfológicas e geológicas. (Ilustração: Carlos Schaefer / Edição: Bruno Mendonça).

FIGURE 1: Representative landscape (out of scale) of the complex formations in Campinaranas and the open Ombrophilous Forest in the PARNA Viruá Park; with respective classes of soils and geomorphological and geological features. (Illustration: Carlos Schaefer / Edition: Bruno Mendonça).

Nas áreas mais abertas, dominadas pelas Campinaranas Gramíneo-Lenhosas, ocorreram os campos de dunas fósseis (ou paleodunas) em áreas de maior exposição aos ventos, que, em fases mais secas de períodos glaciais, promoveram sua ativação e atualmente permaneceram estacionadas e parcialmente vegetadas (SANTOS e NELSON, 1995; CARNEIRO FILHO et al., 2003). Nestas áreas, principalmente próximas aos agrupamentos arbustivos, ocorreram como inclusões Espodossolos Humilúvicos órticos, não hidromórficos, com notáveis evidências da podzolização lateral, em lamelas de espodização. Nas Campinaranas Gramíneo-Lenhosas predominaram os Neossolos Quartzarênicos, em razão do menor aporte de MO dessa fitofisionomia, insuficiente para permitir o acúmulo em superfície e subsuperfície. Nas áreas de lagos interdunas predominaram as formações de buritizais (Figura 1).

Os Espodossolos estudados foram, no $3^{\text {o }}$ nível categórico, Hidromórficos ou Órticos; os Hiperespessos, comumente chamados de "Espodossolos Gigantes", com horizontes espódicos profundos, não amostrados, de 3 a $10 \mathrm{~m}$ (DUBROEUCQ e VOLKOFF, 1988; 1998), no entanto, sua ocorrência é esperada para a região. No $4^{\circ}$ nível categórico são classificados como: arênicos, quando associados às Campinaranas Florestadas e Arbustivas presentes nos interflúvios; espessarênicos, nas dunas inativas com Campinarana Gramíneo-Lenhosa; ou dúricos, nas Campinaranas em contato com as drenagens principais. Estes solos são arenosos, com predomínio de areia fina em todas as fitofisionomias de sua ocorrência, seguido pela areia grossa, silte e argila (Tabelas 2 e 3), o que sugere a origem eólica dessas formações, originárias do retrabalhamento da cobertura sedimentar arenosa dominante (Formação Içá) (BRASIL, 1975; SANTOS e NELSON, 1995; CPRM, 2000). Os solos das Campinaranas Florestadas destacaram-se dos demais por apresentarem menor conteúdo de areia grossa e maior de silte.

De maneira geral, são solos ácidos, pobres e distróficos, com pH entre 4 a 5,5, Soma de Bases (SB) média menor que $0,3 \mathrm{cmol}_{c} \mathrm{dm}^{-3}$ e Saturação por Bases (V) média menor que $3 \%$ (Tabelas $2 \mathrm{e}$ 3). Os horizontes espódicos possuem Saturação de Alumínio (m) média maior que $85 \%$ e rico em carbono orgânico, o que evidencia a formação dos complexos MO-Al (Tabelas 2 e 3). Além disso, os horizontes espódicos, em relação aos demais, apresentaram $\mathrm{pH}$ mais básico, P-Mehlich maior e CTC mais elevada, o que revela a maior afinidade do $\mathrm{P}$ pelos compostos organometálicos presentes.

Nas Campinaranas Arbustivas, destacou-se a presença generalizada de cupinzeiros de coloração escurecida na base dos arbustos, onde, apesar da elevada acidez, os teores de fósforo e a soma de bases foram quase 10 vezes maiores que os horizontes minerais superficiais dos solos adjacentes (Tabela 3). O teor de argila, a CTC e a MO também foram superiores aos solos adjacentes e a saturação 
TABELA 2: Resultado da análise química e física de perfis dos solos representativos do PARNA Viruá e entorno.

TABLE 2: Result of the chemical and physical analysis of representatives soils profiles in PARNA Viruá Park and surrounding.

\begin{tabular}{|c|c|c|c|c|c|c|c|c|c|c|c|c|c|c|c|c|c|c|}
\hline Hor. / Prof. & $\mathrm{pH}$ & $\mathrm{P}$ & $\mathrm{K}$ & $\mathrm{Na}$ & $\mathrm{Ca}$ & $\mathrm{Mg}$ & Al & $\mathrm{H}+\mathrm{Al}$ & SB & $\mathrm{t}$ & $\mathrm{T}$ & $\mathrm{V}$ & $\mathrm{m}$ & MO & AG & $\mathrm{AF}$ & Sil & Arg \\
\hline & $\mathrm{H}_{2} \mathrm{O}$ & --- & $\mathrm{mg}$ & $m^{-3}-$ & & - & $\cdots$ & 1 & & & & ---- 0 & & & & & & \\
\hline \multicolumn{19}{|c|}{ ESPODOSSOLO HUMILÚVICO Hidromórfico arênico - Campinarana Florestada } \\
\hline $\mathrm{O}(0-10)$ & 3,8 & 0,6 & 33,0 & 38,1 & 0 & 0,5 & 3,7 & 26,7 & 0,8 & 4,5 & 27,5 & 2,8 & 83,0 & 40,4 & - & - & - & - \\
\hline $\mathrm{A}(10-15)$ & 4,5 & 2,2 & 15,0 & 11,9 & 0 & 0,5 & 3,2 & 21,1 & 0,5 & 3,8 & 21,6 & 2,5 & 85,7 & 8,8 & 230 & 400 & 260 & 110 \\
\hline $\mathrm{E}(15-23)$ & 5,0 & 2,1 & 3,0 & 0,9 & 0 & 0,4 & 1,4 & 11,9 & 0,4 & 1,9 & 12,3 & 3,5 & 76,9 & 3,4 & 180 & 510 & 230 & 80 \\
\hline $\mathrm{Bh}(23-80)$ & 5,3 & 0,6 & 0 & 0 & 0 & 0,4 & 0,7 & 9,3 & 0,4 & 1,1 & 9,7 & 4,4 & 60,9 & 3,4 & 160 & 470 & 270 & 100 \\
\hline Bhs (80-120) & 5,0 & 0,6 & 0 & 0 & 0 & 0,4 & 0,3 & 3,8 & 0,4 & 0,7 & 4,2 & 10,0 & 40,8 & 3,6 & 170 & 470 & 270 & 90 \\
\hline Bs $(120-180+)$ & ) 4,8 & 0,4 & 0 & 0 & 0 & 0,4 & 0,2 & 1,6 & 0,4 & 0,6 & 2,0 & 20,4 & 31,7 & 0,6 & 200 & 450 & 200 & 150 \\
\hline
\end{tabular}

ESPODOSSOLO HUMILÚVICO Hidromórfico arênico - Campinarana Arbustiva

\begin{tabular}{lcccccccccccccccccc}
\hline $\mathrm{A}(0-10)$ & 4,2 & 4,9 & 30 & 8,3 & 0,1 & 0,1 & 1,3 & 9,8 & 0,3 & 1,6 & 10,1 & 2,9 & 82,1 & 6,1 & 200 & 530 & 230 & 40 \\
$\mathrm{E}(10-60)$ & 4,8 & 1 & 0 & 0 & 0 & 0 & 0,3 & 1,5 & 0,1 & 0,4 & 1,6 & 4,5 & 81,6 & 0 & 300 & 490 & 200 & 10 \\
$\mathrm{Bh}(60-80)$ & 4,3 & 4,1 & 4 & 0 & 0 & 0 & 1,5 & 9,3 & 0,1 & 1,6 & 9,4 & 0,6 & 96,3 & 1,0 & 250 & 480 & 240 & 30 \\
$\mathrm{Bhs}(80-100)$ & 4,8 & 1 & 0 & 0 & 0 & 0 & 1,3 & 2,5 & 0 & 1,4 & 2,5 & 1,6 & 97,1 & 2,6 & 220 & 460 & 240 & 80 \\
$\mathrm{C} 1(100-140)$ & 4,7 & 0,5 & 1 & 0 & 0,2 & 0 & 0,5 & 2,2 & 0,2 & 0,7 & 2,4 & 8,7 & 70,8 & 0,1 & 180 & 480 & 200 & 140 \\
$\mathrm{C} 2(140-200)$ & 4,8 & 0,4 & 1 & 0 & 0,1 & 0 & 0,5 & 1,7 & 0,1 & 0,6 & 1,8 & 5,6 & 83,6 & 0 & 180 & 490 & 190 & 140 \\
\hline
\end{tabular}

NEOSSOLO QUARTZERÊNICO Hidromorfico espódico - Campinarana Gramíneo-Lenhosa

\begin{tabular}{lcccccccccccccccccc}
\hline $\mathrm{EC}(0-15)$ & 5,2 & 1,2 & 1 & 0 & 0 & 0 & 0,41 & 1,7 & 0,02 & 0,43 & 1,72 & 1,2 & 95,3 & 1,14 & 230 & 570 & 190 & 10 \\
$\mathrm{C}(\mathrm{h})(15-85)$ & 5,0 & 1,1 & 0 & 0 & 0 & 0 & 0,1 & 0,7 & 0 & 0,1 & 0,7 & 0 & 100 & 0,25 & 370 & 500 & 120 & 10 \\
$\mathrm{C}(85-100)$ & 5,4 & 1,2 & 0 & 0 & 0 & 0 & 0,1 & 1,9 & 0 & 0,1 & 1,9 & 0 & 100 & 0,38 & 230 & 500 & 240 & 30 \\
$\mathrm{Cr}(100+)$ & 5,2 & 0,5 & 0 & 0 & 0 & 0 & 0,1 & 0,7 & 0 & 0,1 & 0,7 & 0 & 100 & 0,25 & 280 & 500 & 160 & 60 \\
\hline
\end{tabular}

CAMBISSOLO HÁPLICO Tb Distrófico típico - Floresta Ombrófila Aberta

\begin{tabular}{lcccccccccccccccccc}
\hline $\mathrm{O}(0-4)$ & 3,7 & 4,2 & 72 & 9 & 0,54 & 0,46 & 3,08 & 24 & 1,22 & 4,3 & 25,22 & 4,8 & 71,6 & 25,83 & - & - & - & - \\
$\mathrm{A} \mathrm{(4-10)}$ & 3,7 & 2,7 & 39 & 5 & 0,04 & 0,14 & 1,13 & 18,6 & 0,3 & 1,43 & 18,9 & 1,6 & 79 & 10,98 & 120 & 110 & 290 & 480 \\
$\mathrm{AB} \mathrm{(10-17)}$ & 3,7 & 2,5 & 31 & 7,6 & 0,01 & 0,12 & 2,67 & 15,1 & 0,24 & 2,91 & 15,34 & 1,6 & 91,8 & 6,59 & 130 & 110 & 260 & 500 \\
$\mathrm{Bi} \mathrm{(17-35)}$ & 3,9 & 1,9 & 9 & 0 & 0 & 0,06 & 1,74 & 8,5 & 0,08 & 1,82 & 8,58 & 0,9 & 95,6 & 2,97 & 170 & 110 & 280 & 440 \\
$\mathrm{BC}(35-70)$ & 4,2 & 0,6 & 4 & 0 & 0 & 0,05 & 1,23 & 5,9 & 0,06 & 1,29 & 5,96 & 1 & 95,3 & 1,81 & 160 & 90 & 240 & 510 \\
$\mathrm{CR}(70-90+)$ & 4,4 & 0,3 & 2 & 0 & 0 & 0,14 & 1,13 & 5,2 & 0,15 & 1,28 & 5,35 & 2,8 & 88,3 & 1,16 & 130 & 70 & 220 & 580 \\
\hline
\end{tabular}

LATOSSOLO VERMELHO-AMARELO Distrófico típico - Floresta Ombrófila Aberta

\begin{tabular}{lcccccccccccccccccccc}
\hline $\mathrm{O}(3-0)$ & 3,6 & 5 & 54 & 15,6 & 0,06 & 0,19 & 2,87 & 15,7 & 0,46 & 3,33 & 16,16 & 2,8 & 86,2 & 11,63 & - & - & - & - \\
$\mathrm{A}(0-15)$ & 3,5 & 4,9 & 27 & 5 & 0 & 0,1 & 3,49 & 13 & 0,19 & 3,68 & 13,19 & 1,4 & 94,8 & 6,98 & 90 & 320 & 240 & 350 \\
$\mathrm{BA}(15-20)$ & 3,9 & 1,3 & 13 & 3 & 0 & 0,07 & 2,67 & 9 & 0,11 & 2,78 & 9,11 & 1,2 & 96 & 2,84 & 80 & 310 & 230 & 380 \\
$\mathrm{Bw}(20-70)$ & 4,3 & 0,4 & 2 & 0 & 0 & 0,04 & 1,54 & 6,4 & 0,05 & 1,59 & 6,45 & 0,8 & 96,9 & 1,42 & 70 & 330 & 170 & 430 \\
$\mathrm{BC}(70-90)$ & 4,5 & 0,3 & 0 & 0 & 0 & 0,03 & 2,15 & 4,9 & 0,03 & 2,18 & 4,93 & 0,6 & 98,6 & 0,9 & 60 & 240 & 200 & 500
\end{tabular}

NEOSSOLO FLÚVICO Tb Distrófico típico - Floresta de igapó

\begin{tabular}{lcccccccccccccccccc}
\hline $\mathrm{A}(0-10)$ & 3,9 & 14 & 73 & 6,3 & 0,45 & 0,53 & 1,74 & 7,9 & 1,2 & 2,94 & 9,1 & 13 & 59,2 & 4,91 & 0 & 20 & 570 & 410 \\
$\mathrm{C} 1(10-30)$ & 4,1 & 3,5 & 32 & 5,7 & 0 & 0,15 & 2,77 & 6,8 & 0,25 & 3,02 & 7,05 & 3,5 & 91,7 & 2,33 & 0 & 30 & 520 & 450 \\
$\mathrm{C} 2(30-50)$ & 4,5 & 0,7 & 9 & 6,3 & 0 & 0,08 & 3,18 & 7,4 & 0,13 & 3,31 & 7,53 & 1,7 & 96,1 & 1,03 & 0 & 20 & 400 & 580 \\
$\mathrm{C} 3(50-100)$ & 4,9 & 0,3 & 4 & 9,6 & 0 & 0,08 & 3,38 & 6,8 & 0,13 & 3,51 & 6,93 & 1,9 & 96,3 & 0,78 & 10 & 30 & 330 & 630 \\
$\mathrm{C} 4(100-180)$ & 5,4 & 0,2 & 2 & 16,2 & 0 & 0,08 & 2,87 & 6,1 & 0,16 & 3,03 & 6,26 & 2,6 & 94,7 & 0,39 & 20 & 100 & 320 & 560 \\
\hline
\end{tabular}

Em que: $\mathrm{P}$ - Fósforo; $\mathrm{K}$ - Potássio; $\mathrm{Na}$ - Sódio; $\mathrm{Ca}$ - Cálcio; $\mathrm{Mg}$ - Magnésio; Al - Alumínio trocável; $\mathrm{H}+\mathrm{Al}$ - Acidez trocável; SB - Soma de Bases; t - Capacidade de Troca Catiônica efetiva; T - Capacidade de Troca Catiônica a pH 7; V - Saturação por Bases; m - Saturação por Al; MO - Matéria Orgânica; AG - Areia Grossa; AF - Areia Fina; Sil Silte; Arg - Argila. 
de $\mathrm{Al}(\mathrm{m})$ foi menor (Tabela 3 ). Estes resultados evidenciaram a importância dos térmitas na ciclagem de nutrientes, a qual também é reportada pela literatura (BLACK e OKWAKOL, 1997; SCHAEFER, 2001; SARCINELLE et al., 2009). O mesmo ocorre na Campinarana Gramíneo-Lenhosas, um ambiente pouco mais rebaixado, onde o lençol aflora com mais constância. Os termiteiros, nestas condições, além de disponibilizarem nutrientes, permitem a boa aeração do solo e favorecem a fixação das plantas, nestes solos constantemente alagados. Essas observações revelam a notável relação entre os térmitas e a distribuição dos arbustos na paisagem do PARNA Viruá.

\section{Neossolos Quartzarênicos}

Os Neossolos Quartzarênicos são predominantes no PARNA do Viruá (Figura 2). Em média, estes solos possuem características químicas se- melhantes aos Espodossolos da região, são ácidos, pobres e distróficos. O pH varia de 4,1 a 5,6, a SB média menor que $0,1 \mathrm{cmol}_{\mathrm{c}} \mathrm{dm}^{-3} \mathrm{e} \mathrm{V} \%$ médio menor que $2,2 \%$ (Tabelas 2 e 3 ). São solos arenosos, com predomínio de areia fina, seguido de areia grossa, silte e argila (Tabelas 2 e 3). Estes solos possuem camadas superficiais pobres em MO, com média menor que 2,6 dag $\mathrm{kg}^{-1}$ (Tabelas 2 e 3), com horizontes A moderados. A CTC média em todos os horizontes é associada aos teores médios de $\mathrm{MO}$ e evidencia a importância da ciclagem de nutrientes para a vegetação nestes solos quase ausentes em argila (Tabelas 2 e 3). Tais características mostram o oligotrofismo típico destes ambientes, onde a vegetação apresenta-se aberta e com porte reduzido (Figura 1) em razão da escassez de nutrientes.

Os Neossolos Quartzarênicos estudados são hidromórficos com caráter espódico no $4^{\circ}$ nível categórico, ou não se enquadraram nas outras classes

TABELA 3: Resultado da análise química e física com a média e o desvio padrão dos solos estudados no PARNA Viruá e entorno.

TABLE 3: Result of the chemical and physical analysis with the average and the standard deviation of the soils studied in PARNA Viruá park and surrounding.

\begin{tabular}{|c|c|c|c|c|c|c|c|c|c|c|c|c|}
\hline \multirow{2}{*}{ CAMADAS $^{\mathrm{a}}$} & Espessura & \multirow{2}{*}{$\begin{array}{c}\mathrm{pH} \\
\mathrm{H} 2 \mathrm{O}\end{array}$} & \multirow{2}{*}{$\frac{\mathrm{P}}{\mathrm{mg} \mathrm{dm^{-3 }}}$} & SB & $\mathrm{T}$ & $\mathrm{V}$ & $\mathrm{m}$ & \multirow{2}{*}{$\frac{\mathrm{MO}}{\text { dag } \mathrm{kg}^{-1}}$} & $\mathrm{AG}$ & $\mathrm{AF}$ & Silte & \multirow{2}{*}{ Argila } \\
\hline & $\mathrm{cm}$ & & & ----- $\mathrm{cmol}_{\mathrm{c}}$ & $\mathrm{dm}^{-3}----$ & -------- \% & ---------- & & -------- & ------- $\mathrm{g} \mathrm{k}$ & $\mathrm{g}^{-1}--------\cdot$ & \\
\hline \multicolumn{13}{|c|}{ Espodossolos Humilúvicos } \\
\hline Superficial & $6,8 \pm 2,8$ & $4,4 \pm 0,4$ & $2,6 \pm 1,6$ & $0,3 \pm 0,2$ & $15,9 \pm 10,6$ & $2,4 \pm 1,0$ & $87,4 \pm 5,0$ & $7,4 \pm 9,1$ & $253 \pm 48$ & $470 \pm 65$ & $205 \pm 56$ & $73 \pm 38$ \\
\hline Eluvial & $18,3 \pm 13,1$ & $5,1 \pm 0,4$ & $1,5 \pm 0,9$ & $0,1 \pm 0,1$ & $4,0 \pm 4,2$ & $2,1 \pm 1,8$ & $89,2 \pm 8,6$ & $0,8 \pm 1,2$ & $316 \pm 113$ & $533 \pm 113$ & $123 \pm 71$ & $28 \pm 21$ \\
\hline Subsuperficial & $38,0 \pm 31,3$ & $5,1 \pm 0,4$ & $5,7 \pm 11,7$ & $0,1 \pm 0,2$ & $7,1 \pm 6,3$ & $2,9 \pm 5,7$ & $85,2 \pm 23,1$ & $1,2 \pm 1,3$ & $338 \pm 168$ & $460 \pm 119$ & $140 \pm 102$ & $60 \pm 40$ \\
\hline Termiteiros $^{\mathrm{b}}$ & - & $4,0 \pm 0,4$ & $24,1 \pm 25,4$ & $1,9 \pm 1,8$ & $53,5 \pm 14$ & $5,4 \pm 6,9$ & $68,7 \pm 23,7$ & $41,2 \pm 15,9$ & $335 \pm 157$ & $160 \pm 77$ & $298 \pm 94$ & $207 \pm 41$ \\
\hline \multicolumn{13}{|c|}{ Neossolos Quartzarênicos } \\
\hline Superficial & $15,0 \pm 7,3$ & $4,6 \pm 0,5$ & $1,3 \pm 0,6$ & $0,1 \pm 0,0$ & $6,1 \pm 8,7$ & $2,2 \pm 1,9$ & $87,0 \pm 10$ & $2,6 \pm 4,1$ & $263 \pm 122$ & $498 \pm 80$ & $208 \pm 179$ & $30 \pm 21$ \\
\hline Eluvial & $33,3 \pm 11,5$ & $4,7 \pm 0,4$ & $0,4 \pm 0,1$ & 0,0 & $1,4 \pm 0,0$ & $2,1 \pm 0,0$ & $91,7 \pm 3,7$ & $0,1 \pm 0,2$ & $427 \pm 6$ & $480 \pm 17$ & $77 \pm 21$ & $17 \pm 6$ \\
\hline Subsuperficial & $69,7 \pm 3,5$ & $5,3 \pm 0,3$ & $0,7 \pm 0,4$ & 0,0 & $1,2 \pm 0,4$ & $1,5 \pm 1,3$ & $89,4 \pm 11,7$ & $0,1 \pm 0,1$ & $327 \pm 67$ & $480 \pm 20$ & $180 \pm 72$ & $13 \pm 6$ \\
\hline \multicolumn{13}{|c|}{ Cambissolos Háplicos } \\
\hline Superficial & $7,7 \pm 2,6$ & $3,9 \pm 0,4$ & $3,3 \pm 0,7$ & $1,2 \pm 2,3$ & $13,6 \pm 4,4$ & $9,3 \pm 15,8$ & $71,1 \pm 33,6$ & $6,7 \pm 3,0$ & $170 \pm 94$ & $182 \pm 148$ & $237 \pm 53$ & $415 \pm 187$ \\
\hline Subsuperficial & $22,0 \pm 11,5$ & $4,4 \pm 0,3$ & $1,3 \pm 0,5$ & $0,3 \pm 0,6$ & $6,3 \pm 2,3$ & $4,7 \pm 7,5$ & $83,0 \pm 23,8$ & $2,1 \pm 1,1$ & $213 \pm 100$ & $187 \pm 129$ & $250 \pm 39$ & $350 \pm 185$ \\
\hline \multicolumn{13}{|c|}{ Latossolos Vermelho e Vermelho-Amarelos } \\
\hline Superficial & $12,0 \pm 5,7$ & $4,2 \pm 0,6$ & $2,7 \pm 1,5$ & $2,1 \pm 3,0$ & $10,1 \pm 3,8$ & $18,2 \pm 21$ & $52,9 \pm 38,6$ & $4,6 \pm 2,1$ & $165 \pm 120$ & $263 \pm 59$ & $178 \pm 49$ & $395 \pm 152$ \\
\hline Subsuperficial & $31,0 \pm 21,9$ & $4,7 \pm 0,6$ & $0,6 \pm 0,4$ & $0,5 \pm 0,5$ & $5,8 \pm 2,3$ & $9,6 \pm 8,4$ & $58,4 \pm 42,1$ & $1,7 \pm 0,7$ & $108 \pm 87$ & $228 \pm 110$ & $160 \pm 48$ & $504 \pm 197$ \\
\hline \multicolumn{13}{|l|}{ Solos Aluviais } \\
\hline Superficial & $13,0 \pm 5,7$ & $4,5 \pm 0,4$ & $5,1 \pm 4,4$ & $1,2 \pm 0,5$ & $6,9 \pm 2,5$ & $18,4 \pm 10,1$ & $44,1 \pm 23,9$ & $3,0 \pm 1,8$ & $15 \pm 15$ & $550 \pm 301$ & $235 \pm 185$ & $202 \pm 130$ \\
\hline Subsuperficial & $41,3 \pm 18,4$ & $4,7 \pm 0,4$ & $1,2 \pm 1,2$ & $0,3 \pm 0,2$ & $4,9 \pm 1,9$ & $8,5 \pm 8,5$ & $80,9 \pm 19,5$ & $0,7 \pm 0,6$ & $19 \pm 25$ & $440 \pm 342$ & $240 \pm 146$ & $302 \pm 220$ \\
\hline
\end{tabular}

Em que: a São apresentadas as médias ponderadas pela espessura dos respectivos horizontes. A camada superficial representa os horizontes A e/ou AB; a camada eluvial os horizontes E e/ou A2; a camada subsuperficial os horizontes $\mathrm{B}$ e/ou C (somente para os Neossolos Quartzarênicos). ${ }^{\mathrm{b}}$ Os dados correspondem à média de três amostras de termiteiros coletados no entorno dos perfis. P - Fósforo; SB - Soma de Bases; T - Capacidade de Troca Catiônica a pH 7; V Saturação por Bases; m - Saturação por Al; MO - Matéria Orgânica; AG - Areia Grossa; AF - Areia Fina. 
(com horizonte $\mathrm{H}$ hístico ou plíntico) e foram classificados como típicos. O caráter espódico ocorreu nas Campinaranas Gramíneo-Lenhosas, um ambiente predominantemente depressional, onde a biomassa vegetal foi reduzida e o aporte de matéria orgânica em superfície e subsuperfície foram baixos. De maneira geral é um ambiente com "enclave" de vegetação, de clímax edáfico, escleromórfica, adaptada a tolerar extremos de excessos e falta de água.

Todos os horizontes foram essencialmen- te arenosos com estrutura em grãos simples. Os Neossolos Quartzarênicos, principalmente nas áreas dominadas pelas Campinaranas GramíneoLenhosas, apresentaram restrição de drenagem na superfície dos solos, possivelmente associada ao teor médio de silte mais elevado em superfície (Tabela 3); observada após chuvas de curta duração durante a estação seca. Essas condições de drenagem deficiente são relacionadas à predominância da vegetação herbácea.

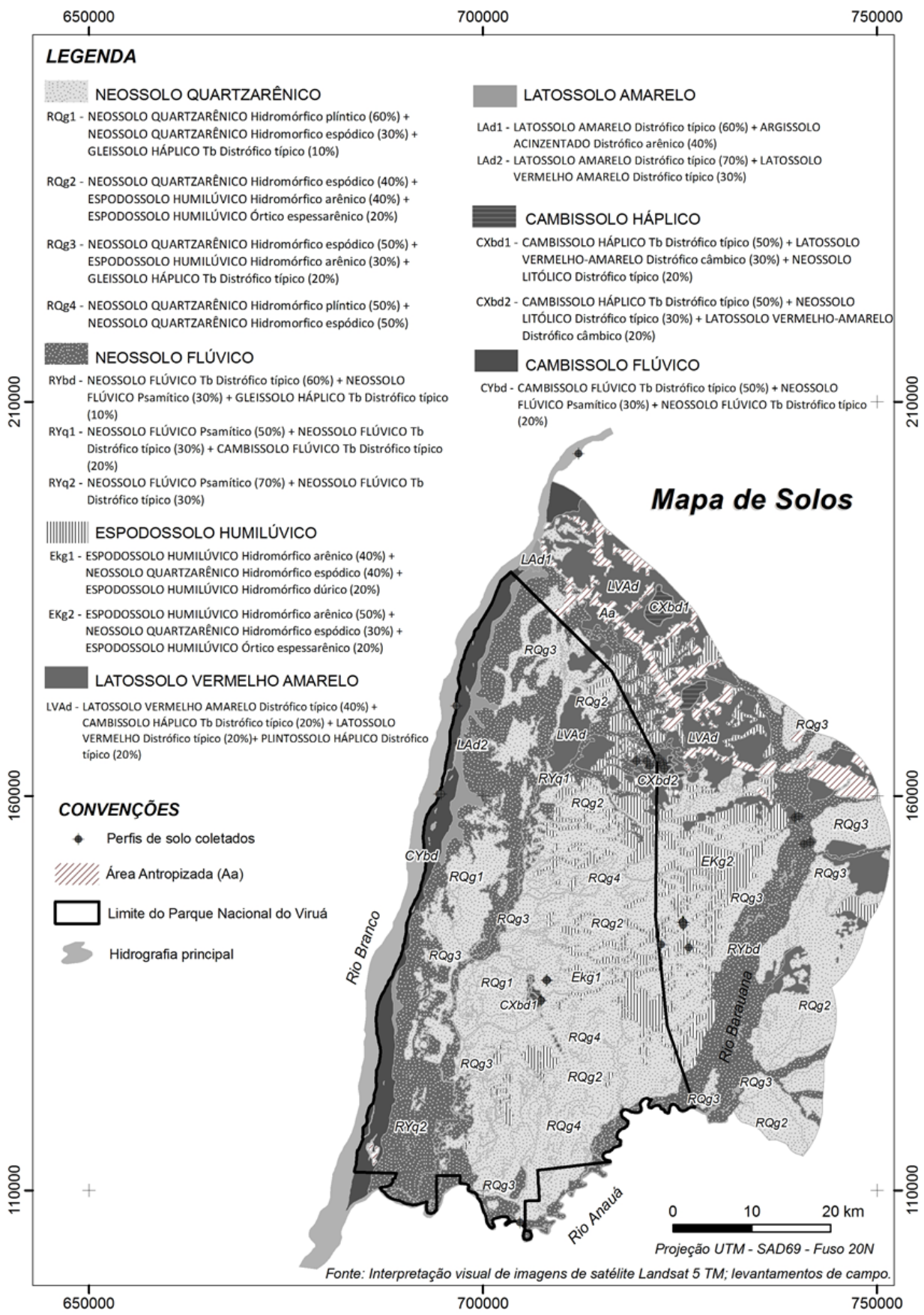

FIGURA 2: Mapa de solos e localização dos perfis de solos estudados.

FIGURE 2: Map of soils and location of the studied soil profiles. 
A vegetação aberta, associadas a estes solos, ocorre em áreas bastante amplas e de grandes extensões no PARNA Viruá e entorno (Figura 2). Estes ambientes apresentam-se muito pobres em recursos mantenedores ou atrativos de subsistência para a sedentarização humana nesta região (SCHAEFER e EDEN, 1995). Trata-se de solos não aptos ao aproveitamento agrícola, mais apropriado à preservação da fauna e flora, como já são destinados no PARNA Viruá. A região de entorno a leste do Parque pertence ao INCRA (Instituto Nacional de Colonização e Reforma Agrária) e nunca foi ocupada (ICMBio, 2009) em razão da baixa capacidade de suporte para a agricultura.

\section{Solos associados aos inselbergs e adjacências}

Os inselbergs são elevações que se destacam de seu entorno já aplainado e caracterizam-se em relevos residuais. No PARNA Viruá, em meio ao relevo baixo e inundado, destacam-se dois importantes relevos residuais pontuais, conhecidos como Serra da Perdida, formados a partir de rochas vulcânicas ácidas do Grupo Iricoumé, e a Serra do Preto, com gnaisses da Suíte Metamórfica Rio Urubu (CPRM, 2000). O relevo montanhoso e florestado contrasta com a parte baixa e aplainada, dominada pelas Campinaranas. Neste relevo residual predominam Latossolos Vermelho-Amarelos e Cambissolos e algumas áreas de solos concrecionários latéricos e hidromórficos (Figura 2). Em contraste com os solos das Campinaranas, estes solos são muito argilosos (Tabelas 2 e 3), provenientes de rochas vulcânicas ácidas e gnaisses; o suficiente para suportar uma vegetação florestal exuberante, mapeada pelo Projeto RADAMBRASIL (BRASIL, 1975) como Área de Tensão Ecológica de Floresta Aberta, favorecida também pelos aspectos climáticos transicionais. Ocorrem ainda pequenas manchas de Florestas Densas.

Os Latossolos Vermelho-Amarelos (LVA) e Vermelhos (LV) são quimicamente pobres, com SB

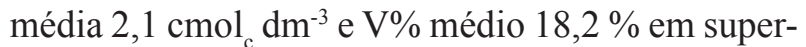
fície, e originários do intemperismo das rochas PréCambrianas (Grupo Iricoumé e Suíte Metamórfica do Rio Urubu), entretanto, com variações de fertilidade, indicadas pelo desvio padrão mais elevado para soma de bases e saturação de bases (Tabelas $2 \mathrm{e}$ 3). Os LV são relacionados com porções mais máficas do material de origem, nos arredores da Serra da Perdida, e por isso são solos de maior fertilidade natural. Os LVAs são mais ácidos, menos férteis e menos argilosos que os LVs, por estarem associados à natureza dos materiais de origem mais alcalino (Grupo Iricoumé). No entanto, ambos ocorrem em relevo plano a suave ondulado nas rampas, colinas, encostas e/ou superfícies pediplanadas e possuem concreções ferruginosas pontuais em degradação. A degradação da canga ferruginosa nestes ambientes tipicamente úmidos são indicações das oscilações climáticas que ocorreram no Pleistoceno e relacionam-se com a gênese desses solos.

Nas serras baixas e inselbergs, onde o declive é mais acentuado, ocorrem os Cambissolos Háplicos em associação com os Neossolos Litólicos e frequentes afloramentos rochosos. Os Cambissolos coletados possuem até $0,6 \mathrm{~m}$ de profundidade de horizonte $\mathrm{Bi}$ (incipiente), são ácidos, com pH médio de 3,9; muito distróficos, com média de $9 \%$ de saturação por bases; pouco férteis, com SB média $1,2 \mathrm{cmol}^{\mathrm{dm}^{-3}}$; e argilosos, com valor médio de 41,5 dag kg-1 de argila (Tabelas 2 e 3). Na Serra da Perdida, o material de origem é constituído por dacitos e rochas alcalinas, de origem vulcânica do Grupo Iricoumé (CPRM, 2000), e corrobora com a natureza pobre e ácida dos solos (Tabelas 2 e 3 ). $\mathrm{Na}$ Serra do Preto, os solos são ainda mais pobres quimicamente e são franco-argilosos, também em razão da natureza mais ácida do material de origem. Foram coletados 5 perfis de Cambissolos Háplicos, dentre eles, apenas um encontra-se no ambiente de transição Floresta/Campinarana, no entorno da Serra da Perdida, sendo, portanto, um solo mais arenoso, o que explica o desvio padrão alto da argila indicado na Tabela 3. Os outros foram amostrados em duas topossequências. Em ambas, observou-se um aumento no conteúdo de MO com o aumento da altitude (desnível médio de $250 \mathrm{~m}$ ), provavelmente associado às temperaturas mais baixas, à menor atividade biológica e consequente taxas menores decomposição da MO.

Próximo às drenagens situadas nos arredores das serras, onde são comuns as oscilações do lençol freático, destacaram-se os solos com características típicas de processos de oxirredução. A natureza argilosa destes solos, rico em ferro, e a localização nas áreas mais rebaixadas, somadas à precipitação elevada da região, favorecem a gênese de mosqueados e gleização. Foram amostrados apenas dois perfis representativos desses solos: Plintossolo Háplico Distrófico típico e Gleissolo Háplico Tb Distrófico típico. Assim como os outros solos de ocorrência nas adjacências da serra, estes solos também são ácidos, possuem SB baixa $\left(\leq 0,9 \mathrm{cmol}_{\mathrm{c}} \mathrm{dm}^{-3}\right)$ e são argilosos. 


\section{Solos Aluviais}

De modo geral, são solos que possuem sequência errática de textura, com variação desde arenosa a muito argilosa, em camadas estratificadas, sem relação pedogenética entre si; as quais são observadas pelo desvio padrão alto na análise granulométrica (Tabela 3). Foram descritos e coletados 6 perfis de solo com influência fluvial, Neossolos Flúvicos (3) e Cambissolos Flúvicos (3), coletados nas margens do Rio Branco e Rio Barauana. São áreas inundáveis com periodicidade, denominadas de várzeas ou igapós, dependendo das características fitossociológicas da vegetação e dos sedimentos transportados pelos rios. Os solos são pobres, com SB média $1,2 \mathrm{cmol}_{\mathrm{c}} \mathrm{dm}^{-3}$, e com $\mathrm{V} \%$ médio de $18,4 \%$ (Tabela 3 ).

Nas margens do rio Branco, ocorrem formações inundáveis denominadas de florestas de várzea, associadas a tabuleiros e terraços baixos, holocênicos, com solos hidromórficos sazonais. $\mathrm{O}$ estágio sucessional arbóreo é assemelhado à floresta de igapó, formando extensas reentrâncias e alinhamentos de paleomeandros. No rio Barauana, a área inundável apresenta largura variável, que acompanha lateralmente as sinuosidades da planície fluvial, estabelecendo fácies de transição, com florestas de várzeas e de igapós. Estes solos são um pouco mais férteis que os solos estudados no Rio Branco.

De maneira geral, em termos de representatividade espacial, estes solos foram os mais férteis da região (Tabela 3; Figuras 2 e 3), pois recebem sedimentos depositados pelos rios periodicamente. Apesar disso, apresentam, em sua maioria, aptidão agrícola restrita para culturas de ciclo curto e inaptas para culturas de ciclo longo; no Barauana são, inclusive, inaptos para uso agrícola e pastoreio extensivo (BRASIL, 1975).

\section{Unidades Geoambientais e Estoque de Carbono no Solo}

A partir das características geomorfológicas, da cobertura vegetal e dos solos, foram individualizadas 18 unidades geoambientais no Parque Nacional do Viruá e entorno (Figura 3). Na Tabela 4 são apresentados apenas os 16 geoambientes presentes no Parque. O estoque relativo de carbono (em $\mathrm{kg} \mathrm{m}^{-2}$ ) corresponde aos horizontes mais profundos dos solos estudados. Neste contexto, cada geoambiente foi associado a uma unidade de mapeamento dos solos, representada pelos solos predominantes e suas respectivas associações e, assim como os solos, os geoambientes foram agrupados de acordo com características de destaque e aspectos geomorfológicos (Tabela 4).

Os geoambientes predominantes no Parque foram: Pap, Pit, Tci e Mfi; com, respectivamente, $24,6 \%, 20,1 \%, 12,6 \%$ e 10,3\% de área (Tabela 4). Tais ambientes são constantemente inundados e possuem vegetação típica adaptada a essas características, as Campinaranas e as Florestas de Igapó. Os solos são arenosos, com destaque para os Neossolos Quartzarênicos Hidromórficos e os Espodossolos Humilúvicos Hidromórficos, originários das coberturas Holocênicas retrabalhadas pelos ventos.

Em termos de estoque total de carbono nos solos do Parque, destacaram-se os Complexos arenosos das Campinaranas e associações, com 9450,9 Gg C (Tabela 4 e Figura 3). Destacam-se os geoambientes Mpa, Tci e Cab com grande importância para o serviço ambiental de conservação do carbono nos solos. Apesar do porte reduzido dessas formações vegetais, de baixa biomassa aérea, esses geoambientes apresentam grande importância para a conservação do carbono no solo e no ambiente. A natureza quartzosa dos solos em associação com as características geomorfológicas configura um ambiente de baixa fertilidade, ácido e sob inundações periódicas, onde a vegetação é naturalmente condicionada por restrições severas. Nestas áreas, há restrições para a atividade microbiológica do solo, tanto pelas condições de falta de oxigênio dos ambientes alagados, como pela quase ausência de nutrientes, decomposição lenta da matéria orgânica, ou ainda, a presença de materiais vegetais mais recalcitrantes. Assim, mesmo nas condições climáticas atuais (clima tropical chuvoso) favoráveis à decomposição da matéria orgânica, esses ambientes armazenam mais carbono nos solos, quando comparados com as áreas de domínio florestal, em solos mais argilosos. No entanto, com a quase ausência de argila nos solos, parte da matéria orgânica pode ser lixiviada para o lençol freático e levada para as drenagens, as quais, por estas razões, são denominadas de águas pretas (SIOLI, 1965).

De maneira geral, as Campinaranas Florestadas possuem horizontes $\mathrm{O}$ com $0,1 \mathrm{~m}$ de espessura, não incluídos nos cálculos de estoque de $\mathrm{C}$ do solo, o que reforça ainda mais a importância destes geoambientes para o serviço ambiental de conservação do carbono. Nestas áreas ocorrem Espodossolos Humilúvicos Hidromórficos arênicos. Entretanto, estes solos possuem diferenças morfológicas de cor e maior estoque de matéria orgânica em subsuperfície quando comparados com os mesmos 


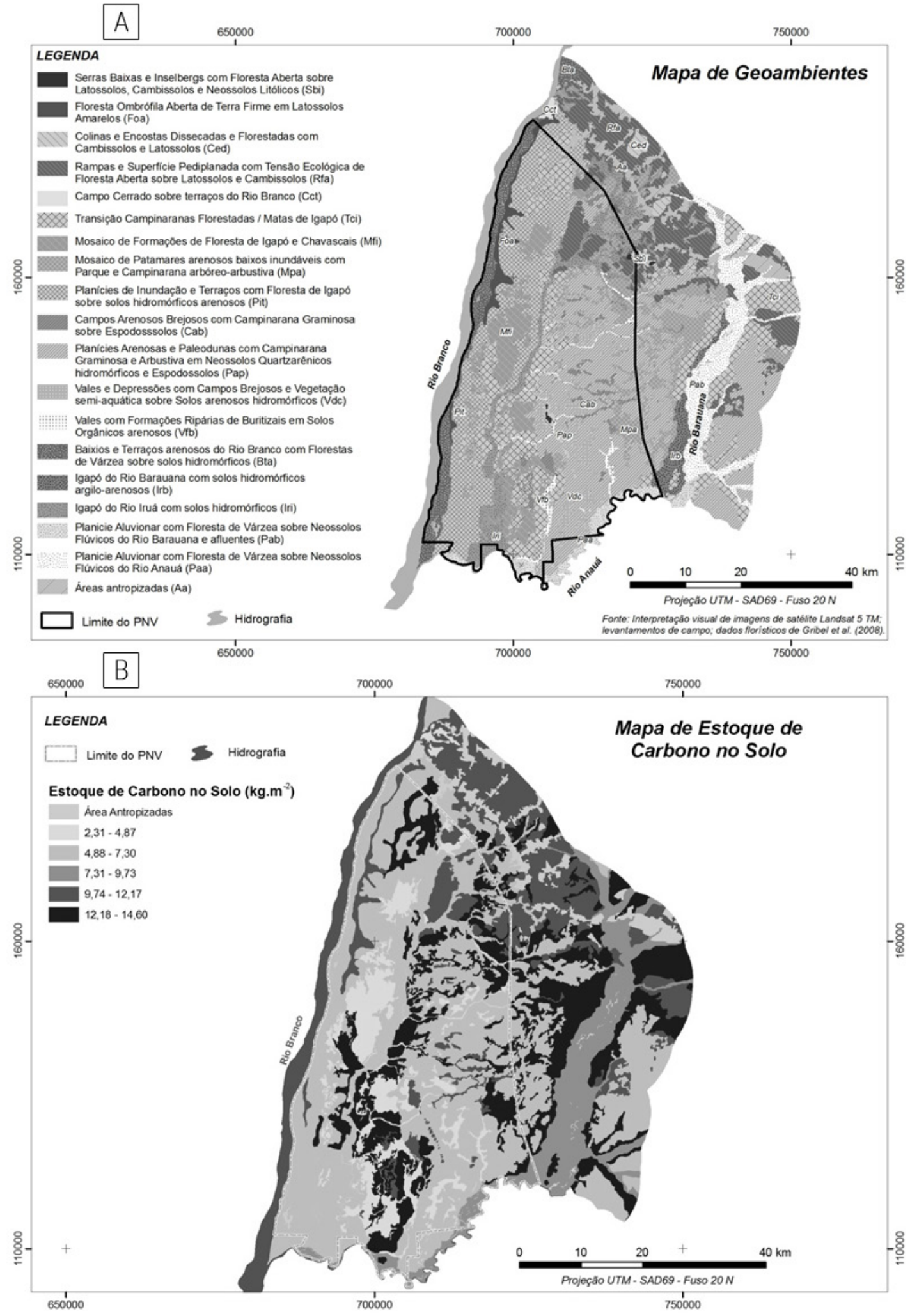

FIGURA 3: Mapas de unidades geoambientais (A) e estoque de carbono no solo (B) do PARNA Viruá e entorno.

FIGURE 3: Maps of geo-environments units (A) and soil carbon stock (B) of PARNA Viruá Park and surroundings. 
TABELA 4: Estoque de carbono e área (ha e \%) dos geoambientes do PARNA do Viruá (RR).

TABLE 4: Carbon stocks and area (ha and \%) of the geoenvironments in PARNA Viruá Park, in Roraima state.

\begin{tabular}{|c|c|c|}
\hline GEOAMBIENTES & $\begin{array}{c}\text { ESTOQUE DE } \\
\mathrm{C} \\
\left(\mathrm{kg} \mathrm{m}^{-2}\right) \\
\end{array}$ & $\begin{array}{l}\text { Área } \\
(\text { ha / \%) }\end{array}$ \\
\hline \multicolumn{3}{|l|}{ Geoambientes associados aos inselbergs e adjacências } \\
\hline Colinas e Encostas Dissecadas e Florestadas com Cambissolos e Latossolos (Ced) & 10,1 & $732,2 / 0,3$ \\
\hline $\begin{array}{l}\text { Serras Baixas e Inselbergs com Floresta Aberta sobre Latossolos, Cambissolos e } \\
\text { Neossolos Litólicos (Sbi) }\end{array}$ & 10,7 & $271,8 / 0,1$ \\
\hline Floresta Ombrófila Aberta de Terra Firme em Latossolos Amarelos (Foa) & 11,0 & $4256,2 / 2,0$ \\
\hline $\begin{array}{l}\text { Rampas e Superfície Pediplanada com Tensão Ecológica de Floresta Aberta sobre } \\
\text { Latossolos e Cambissolos (Rfa) }\end{array}$ & 11,0 & $6797,8 / 3,1$ \\
\hline Complexos arenosos das Campinaranas e associacões & $1319,0 \mathrm{Gg} \mathrm{C}$ & \\
\hline Campos Arenosos Brejosos com Campinarana Graminosa sobre Espodossolos (Cab) & 10,3 & $4648,9 / 2,1$ \\
\hline $\begin{array}{l}\text { Mosaico de Patamares arenosos baixos inundáveis com Parque e Campinarana } \\
\text { arbóreo-arbustiva (Mpa) }\end{array}$ & 14,6 & $12828,0 / 5,9$ \\
\hline $\begin{array}{l}\text { Planícies Arenosas e Paleodunas com Campinarana Graminosa e Arbustiva em } \\
\text { Neossolos Quartzarênicos hidromórficos e Espodossolos (Pap) }\end{array}$ & 5,0 & $\begin{array}{c}53237,3 / \\
24,6\end{array}$ \\
\hline Transição Campinaranas Florestadas / Matas de Igapó (Tci) & 13,4 & $\begin{array}{l}27299,1 / \\
12,6\end{array}$ \\
\hline Vales com Formações Ripárias de Buritizais em Solos Orgânicos arenosos (Vfb) & 2,4 & $3301,7 / 1,5$ \\
\hline $\begin{array}{l}\text { Vales e Depressões com Campos Brejosos e Vegetação semiaquática sobre Solos } \\
\text { arenosos hidromórficos (Vdc) }\end{array}$ & 2,4 & $5060,7 / 2,3$ \\
\hline Mosaico de Formações de Floresta de Igapó e Chavascais (Mfi) & 2,6 & $\begin{array}{l}22252,2 / \\
10,3\end{array}$ \\
\hline
\end{tabular}

Geoambientes de origem fluvial

Estoque total $9450,9 \mathrm{Gg} \mathrm{C}$

Baixios e Terraços arenosos do Rio Branco com Florestas de Várzea sobre solos hidromórficos (Bta)

Igapó do Rio Barauana com solos hidromórficos argilo-arenosos (Irb)

$7,1 \quad 13323,4 / 6,2$

Planícies de Inundação e Terraços com Floresta de Igapó sobre solos hidromórficos

arenosos (Pit)

$8,7 \quad 234,8 / 0,1$

Planície Aluvionar com Floresta de Várzea sobre Neossolos Flúvicos do Rio Anauá

(Paa)

$6,6 \quad 43425,9 /$

20,1

Igapó do Rio Iruá com solos hidromórficos (Iri)

$8,7 \quad 4325,5 / 2,0$

$7,0 \quad 13275,8 / 6,1$

Estoque total $5138,1 \mathrm{Gg} \mathrm{C}$

solos encontrados nas Campinaranas Arbustivas e Gramíneo-Lenhosas, localizados a poucos metros de distância um do outro. Essas considerações foram relevantes para o cálculo das estimativas de estoque de carbono em cada unidade geoambiental apresentado na Tabela 4.

Em média, no PARNA Viruá os estoques de carbono orgânico nos Espodossolos foram $17,55 \mathrm{~kg} \mathrm{~m}^{-2}$; para Cerri et al. (1996), o conteúdo médio de carbono, em até $1 \mathrm{~m}$, nestes solos foi de $18,53 \mathrm{~kg} \mathrm{~m}^{-2}$; e para Batjes e Dijkshoorn (1999), o conteúdo médio de carbono orgânico foi $13,32 \mathrm{~kg} \mathrm{~m}^{-2}$. Alguns trabalhos (CERRI et al., 1996;
BATJES e DIJKSHOORN, 1999; BERNOUX et al., 2002) reportam para estes solos um dos maiores estoques de carbono orgânico, dentre os solos predominantes da região amazônica. De acordo com Bernoux et al. (2002), na região amazônica, as áreas com maior estoque de carbono orgânico nos solos corresponde àquelas sob domínio de solos arenosos, na bacia do Rio Negro.

Os Neossolos Quartzarênicos apresentaram os menores estoques de C no PARNA Viruá, com 2,5 $\mathrm{kg} \mathrm{m}^{-2}$. De acordo com Cerri et al. (1996), o conteúdo médio de carbono orgânico nestes solos para a Amazônia é de 9,4 $\mathrm{kg} \mathrm{m}^{-2}$; para Batjes e Dijkshoorn 
(1999), o conteúdo médio de carbono orgânico até $1 \mathrm{~m}$ é $4,01 \mathrm{~kg} \mathrm{~m}^{-2}$.

Os geoambientes associados aos inselbergs e adjacências possuem os estoques totais de $\mathrm{C}$ no solo mais baixos do PARNA Viruá, com 1319,0 Gg C, em razão da menor extensão dos geoambientes (Tabela 4). Entretanto, mesmo com aporte menor de matéria orgânica em superfície, comparados com os solos das Campinaranas, estes solos também apresentam importantes estoques de $\mathrm{C}$ em subsuperfície em uma distribuição um pouco mais homogênea (Tabela 2), muitas vezes, em razão da atividade da meso e macrofauna, com destaque para os térmitas (SCHAEFER, 2001).

Para os geoambientes de origem fluvial, destacaram-se os geoambientes relacionados aos rios Barauana e Anauá com maior estoque de $\mathrm{C}$ no solo, $8,7 \mathrm{~kg} \mathrm{~m}^{-2}$ : Irb, com pequena representatividade no Parque, apenas em sua porção sudeste; e Paa, na região sul (Tabela 4 e Figura 3).

Em termos de estoque total na área do PARNA Viruá, destacaram-se, em ordem decrescente, os seguintes geoambientes: Tci com 3658,1 Gg C; Pit com 2866,1 Gg C ha-1 ; Pap com 2661,9 Gg C ha-1; e Mpa com 1872,9 Gg C ha ${ }^{-1}$. São notáveis os geoambientes associados aos solos arenosos e hidromórficos, os quais variam desde Neossolos Quartzarênicos e Espodossolos até Neossolos e Cambissolos Flúvicos. Além de exportarem os compostos orgânicos para os cursos d'água, dando a coloração dos rios de águas pretas, estes solos sequestram grande parte do carbono incorporado pela vegetação. Estas considerações são evidências da prestação dos serviços ambientais de conservação do carbono nos solos predominantes das Campinaranas.

\section{CONCLUSÕES}

1) A ampla diversidade de ambientes do Parque Nacional do Viruá e entorno é representada pela distribuição de 18 geoambientes. A grande extensão e representatividade dos complexos arenosos das Campinaranas identificados no mapeamento fazem do PARNA Viruá uma Unidade de Conservação - UC de proteção integral com forte vocação para preservação e conservação de sistemas arenícolas amazônicos.

2) De modo geral, todos os solos estudados apresentam baixa fertilidade e variações texturais, determinadas pela natureza dos materiais de origem. Pequenas variações da fertilidade também são expli- cadas pelas características geomorfológicas, como por exemplo, a altimetria, a proximidade das drenagens e as áreas de acumulações. Destaca-se a relação entre a ocorrência dos térmitas e a distribuição das espécies arbóreo-arbustivas nas Campinaranas Arborizadas e Gramíneo-Lenhosas.

3) A granulometria dos solos condiciona a ocorrência da cobertura vegetal com fitofisionomias distintas, a saber, campinaranas e florestas. O predomínio da fração areia fina nos solos das campinaranas e os estudos geológicos precedentes, sugerem a origem eólica desses sedimentos. As florestas são associadas aos solos argilosos ou argilo-arenosos e possuem caráter transicional com as campinaranas e as diferentes fácies de floresta aberta e densa, em razão das condições edáficas e climáticas.

4) O comportamento hidrológico dessa região, com inundações periódicas e de grande extensão e magnitude, possui correlações diretas com a ocorrência das fitofisionomias, sendo determinantes mesmo em pequenas distâncias e com variações altimétricas.

5) No Parque Nacional do Viruá, as áreas sob o domínio de Espodossolos possuem os maiores estoques de carbono orgânico e, portanto, estes solos são extremamente importantes nas análises de sequestro e emissão de carbono.

6) Os complexos arenosos das Campinaranas e associações representam os geoambientes mais relevantes na prestação de serviços ambientais de conservação do carbono nos solos do PARNA Viruá.

\section{AGRADECIMENTOS}

Agradecimentos ao Programa de Áreas Protegidas da Amazônia (Programa ARPA), ao ICMBio (Roraima), a equipe do Parque Nacional do Viruá e ao CNPq pelo apoio e financiamento deste trabalho.

\section{REFERÊNCIAS BIBLIOGRÁFICAS}

AB'SABER, A. N. Bases para o estudo dos ecossistemas da Amazônia brasileira. Estudos Avançados. v. 16, p. 45, 2002.

ALTEMULLER, H. J; KLINGE, H. Micromorphological investigation on development of podzol in Amazon basin. Plön, Max Plank Institute of Limnology. Soil Micromorphology, p. 295-305. 1964.

ANA, Agência Nacional de Águas. Sistemas de Informações Hidrológicas. Estação meteorologica 
de Caracaraí. Disponível em: < (http://www.ana. gov.br) $>$ Acesso em 5 de maio de 2009.

ANDRADE, $H$. et al. Pedogeomorfologia e micropedologia de uma seqüência de Latossolo - Areia Quartzosa Hidromórfica sobre rochas cristalinas do Estado do Amazonas. Genomos. Belo Horizonte, v. 5, n. 1, p. 55-66. 1997.

ANDRADE, H. Evolução de uma seqüência de solos argilosos até arenosos no Complexo Guianense da Amazônia. 1990. 179 f. (Tese de Doutorado) - Escola Superior de Agricultura "Luiz de Queiroz", Piracicaba, 1990.

BATJES, N. H.; DIJKSHOORN, J. A. Carbon and nitrogen stocks in the soils of the Amazon Region. Geoderma v. 89, p.273-286, 1999.

BERNOUX, M. Conteúdo de carbono dos solos da Amazônia ocidental e mudanças decorrentes da conversão da floresta em pastagens. 1998, $98 \mathrm{f}$. (Tese de Doutorado) - Centro de Energia Nuclear na Agricultura, Universidade de São Paulo, Piracicaba, 1998.

BERNOUX, M. et al. Brazil's Soil Carbon Stocks. Soil Sci. Soc. Am. J. v. 66, p. 888-896, 2002.

BERNOUX, M. et al. Bulk densities of Brazilian Amazon soils related to other soil properties. Soil Sci. Society of America Journal, v. 62, n. 3, p. 743-749, 1998.

BLACK, H. I. J.; OKWAKOL, M. J. N. Agricultural intensification, soil biodiversity and agroecosystem function in the tropics: the role of termites. Applied Soil Ecology, v. 6, p. 37-53. 1997.

BOULET, R., CHAUVEL, A., LUCAS, Y., Les systems de transformation en pédologie. AFES, Livre Jubiliaire du Cinquantenaire, Plaisir, France, p.167-179. 1984.

BRASIL. Ministério das Minas e Energia. Projeto RADAMBRASIL - Levantamento dos Recursos Naturais. Folha NA. 20 Boa Vista e parte das Folhas NA -21 Tumuqumaque, NB - 20 Roraima e NB - 21, Rio de Janeiro, 1975. 428 p. v. 8.

BRAVARD, S.; RIGHI, D. Micromorphology of an Oxisol-Spodosol catena in Amazonia. In: L. A. Douglas Soil Micromorphology: a basic and applied science. Amsterdam, Elsevier, 1990. p 169174. (Developments in Soil Science, 19)

CARNEIRO FILHO A., TATUMI S. H., YEE M. Dunas Fósseis na Amazônia. Ciência Hoje, v. 191, p. 24-29. 2003.

CERRI, C. C. et al. Dinâmica do carbono nos solos da Amazônia. In: ALVAREZ V., V. H.; FONTES, L. E. F. e FONTES, M. P. F. Os solos nos grandes domínios morfoclimáticos do Brasil e o desenvolvimento sustentável. Viçosa, Sociedade Brasileira de Ciência do Solo, 1996. p.61-69.

CPRM, Companhia de Pesquisa de Recursos Minerais. Programa Levantamentos Geológicos Básicos do Brasil. Projeto de Mapeamento Geológico / Metalogenético Sistemático Caracaraí, Folhas NA.20-Z-B e NA.20-Z-D inteiras e parte das folhas NA.20-Z-A, NA.20-Z-C, NA.21-Y-C e NA.21-Y-A. Estado de Roraima. Escala 1:500.000. Brasília: 2000.

DEFELIPO, B. V.; RIBEIRO, A. C. Análise Química do Solo. 2. ed. Viçosa: UFV, 1997.26 p. (Boletim de extensão, 29)

DUBROEUCQ, D.; VOLKOFF, B. Évolution des couvertures pédologiques sableuses à podzols géants d'Amazonie (Bassin du Haut rio Negro). Cah. ORSTOM, sér. Pedol., v. 24, n. 3, p. 191-214. 1988.

DUBROEUCQ, D.; VOLKOFF, B. From Oxisols to Spodosols and Histosols: evolution of the soil mantles in the rio Negro basin (Amazonia). Catena, v. 32, p. 245-280, 1998.

DUBROEUCQ, D.; VOLKOFF, B.; PEDRO, G. La couverture pédologique du bouclier du nord de 1'Amazonie (bassin du Haut rio Negro). Séquence évolutive des sols et son role dans l'aplanissement généralisé des zones tropicales perhumides. C. R. Acad. Sci., Sér. II, v. 312, p. 663-671, 1991.

EMBRAPA, Empresa Brasileira de Pesquisa Agropecuária. Serviço Nacional de Levantamento e Conservação de Solos. Sistema Brasileiro de Classificação de Solos. Rio de Janeiro, 2006.

FEARNSIDE, P. M. A floresta amazônica nas mudanças globais. Manaus, INPA. 2003. 134 p. HOUGHTON, J. T. et al. Revised 1996 IPCC guidelines for national greenhouse gas inventories: Reference manual. London: IPCC/ OECD/IEA. 1997.

ICMBio. Instituto Chico Mendes de Conservação da Biodiversidade. Relatório Plurianual 20052008. Programa de Pesquisa e Monitoramento do Parque Nacional do Viruá. Caracaraí, RR. 37p. Set. 2009.

LUCAS Y. et al. Transição Latossolos-podzóis sobre a formação Barreiras na região de Manaus, Amazônia. R. Bras. Ci. Solo, v. 8, p. 325-335, 1984. MAFRA, A. L. et al. Pedogênese numa seqüência Latossolo-Espodossolo na região do alto rio Negro, Amazonas. R. Bras. Ci. Solo, v. 26, p. 381-394, 2002.

RUIZ, H. A. Incremento da exatidão da análise granulométrica do solo por meio da coleta da 
suspensão (silte + argila). Rev. Bras. Ciência do Solo, Viçosa, v. 29. p. 297-300, 2005.

SANTOS, J. O. S; NELSON, B. W. 1995. Os campos de dunas do Pantanal Setentrional. In: CONGRESSO LATINO-AMERICANO, 8., 1995, Caracas. Temário 4. Caracas, Venezuela, 1995. 9 p. SANTOS, R. D. et al. Manual de descrição e coleta de solo no campo. 5. ed. rev. e ampl. Viçosa, Sociedade Brasileira de Ciência de Solo, 2005.

SARCINELLE, T. S. et al. Chemical, physical and micromorphological properties of termite mounds and adjacent soils along a toposequence in Zona da Mata, Minas Gerais State, Brazil. Catena v. 76, p. 107-113. 2009.

SCHAEFER C. E. G. R. et al. Soil and vegetation carbon stocks in Brazilian Western Amazonia: relationships and ecological implications for natural landscapes. Environ Monit Assess. v. 2007, p. $1-15,2007$

SCHAEFER, C. E. G. R. Ecogeography and human scenario in northeast Roraima, Brazil. Ciência e Cultura Journal of the Brazilian Association for the Advancement of Science. v. 49, n. 4, p. 241252. 1997.

SCHAEFER, C. E. G. R. et al. Elementos da Paisagem e a Gestão da Qualidade Ambiental. Informe Agropecuário, v. 21, jan/fev. 2000.

SCHAEFER, C.E. G. R.; EDEN, M. Os solos e os povos indígenas de Roraima: um ensaio de ecologia humana. In: CONGRESSO BRASILEIRO DE CIÊNCIA DO SOLO, 25., 1995, Viçosa. Anais... Viçosa. Sociedade Brasileira de Ciência do Solo. 1995. p. 1494-1496.

SCHAEFER, C.E.R G. Brazilian latosols and their B horizon microstructure as long-term biotic constructs. Aust. J. Soil Res., 39, 909-926. 2001.

SIMAS, F. N. B. et al. Chemistry, mineralogy and micropedology of highland soils on crystalline rocks of the Serra da Mantiqueira, southeastern Brazil. Geoderma (Amsterdam), v. 125, p. 187-201, 2005. TRICART, J.; KIEWITDEJONGE, C. Ecogeography and rural management. Harlowl: Longman Scintific, 1992.

UN-FCCC (United Nations Framework Convention on Climate Change). Kyoto Protocol to the United Nations Framework Convention on Climate Change, Document FCCC/CP/1997;7/Add1. 1997. VELOSO H. P., RANGEL FILHO, A. L.; ALVES LIMA. Classificação Da Vegetação Brasileira, adaptada a um Sistema Universal. Ministério da Economia, Fazenda e Planejamento. Fundação Instituto Brasileiro de Geografia e Estatística IBGE. Diretoria de Ciências. Departamento de Recursos Naturais e Estudos Ambientais - DERNA. 1991. YEOMANS, J. C.; BREMNER, J. M. A rapid and precise method for routine determination of organic carbon in soil. Commun. Soil Sci. Plant Anal. 19(13): 1467- 1476. 1988. 